\title{
Stage IV Breast Cancer AJCC v6 and v7
}

National Cancer Institute

\section{Source}

National Cancer Institute. Stage IV Breast Cancer A/CC v6 and v7. NCI Thesaurus. Code C3995.

Stage IV includes: Any T, Any N, M1. M1: Distant metastasis. (AJCC 6th and 7th Eds.) 